55. Medical Report of the Royal Lunatic Asylum of Aberdeen. (Robert Jamieson, M.D., Physician and Superintendent.)

56. Lunatic Hospital, The Coppice, near Nottingham. Tenth Annual Report. (W. B. Tate, Medical Superintendent.)

57. Report of the Royal Lunatic Asylum of Montrose. (Medical Superintendent, James C. Howden, M.D.)

58. The Trenty-tirst Report of the Committee of Visitors of the County Lunatic Asylum at Hanwell, January Quarter Bessions, 1866.

\title{
American Reports.
}

Sixth Annual Report of the Board of Directors and Offecrs of the Longview Asylum, Ohio. (O. M. Langdon, M.D., Superintendent and Physician.)

\section{Appointmonts.}

Browne, J. C., M.D. Idin., has been elected Medical Superintendent of the West Riding of Yorkshire Lunatio Asylum at Wakefield.

P. J. Bimpson, M.R.O.S.E., L.S.A., late Resident Modical Officor of the Westminster General |Dispensary, has been elected Apothocary to the Colney Hatch Asylum.

W. Watkins, J. P., M.R.C.S.E., L.S.A., has been appointed Resident Surgeon to the Lunatic Asslum and General Hospital, Berbice, British Guiana.

Stewart, Hugh Grainger, M.D., F.R.C.P., Edin., has been appointed Medical Superintendent to the Newcastle-on-Tyne Borough Lunatic Asylum.

\section{Obituary.}

The late Sir Charles Hastings, M.D., D.C.I., Oxon.

At the first General Meeting for 1866 of the British Medical Association, held at Chester, the.following resolution moved by Dr. Jeaffreson, the retiring President, and seconded by Mr. Carden, of Worcester, was unanimously adopted :

"That the British Medical Association, assembled at the general meeting at Chestor, desires to express its deep sorrow at the loss the desociation has sustained in the death of its much-loved and highly estoemed fousuder, President of Council, und Treasurer, Sir Charles Hastings, who, from the period of its establishment to the present time. has, with singular courtesy and fidelity, exerted his highest powers for. the promotion of the best interests of the Association; and that a copy of this resolution be forwoarded by the President to the family of the late Sir Charles Hastings, with the condolence of the Lssociation on the bereccoement they have sustained."

We cordially concur in the above resolution. Sir Charles Hastings was President of the Medico-Psychological Association in 1859, and he took great interest in the advancement of Mental Psychology.

The late Right Reverend Bishop Willeon.

The late Bishop Willson, of Hobart Town, an honorary member of the Medico-Psychological Association since its foundation, died at Nottingham on the 30th June last, aged 71. He was consecrated Roman Catholic Bishop of 
Hobart Town in 1842. Bishop Willson was an active and energetic advocate of colonial asylum reform, and he worthily represented in Australia the opinions and teaching of this Association.

Dr. Greenup, formerly of Salisbury, for the last fourteen years Superintell. dent of the Parramatta (New South Wales) Lunatic Asylum, holding also the offices of Medical Adviser to the Government and Examiner of Sydney University, has been stabbed by one of the patients in the Asylum, and died in two days after much suffering. His last words were, "No one is to blame for it." He fell a victim to his liumane disposition, which led him to be too trustful even of men confined in the criminal division of the Asylum. - Sydney Morning Herald,' quoted in 'Medical Times,' Sopt. 22.

\section{Notice to Correspondents.}

English books for review, pamphlets, exchange journals, \&c., to be sent either by book-post to Dr. Robertson, Hayward's Heath, Sussex; or to the care of the publishers of the Journal, Messrs. Ciurchill and Sons, New Burlington Street. French, German, and American publications may be forwarded to Dr. Robertson, by foreign book-post, or to Messrs. Williams and Norgate, Henrietta Street, Covent Garden, to the care of their German, French, and American agents, Mr. Hartmann, Leipzig; M. Borrari, 9, Rue de St. Pères, Paris; Messrs. Westermann and Co., Broadway, New York.

Authors of Original Papers wishing Reprints for private circulation can have them on application to the Printer of the Journal, Mr. Adlard, Bartholomew Close, E.C., at a fixed charge of 30s. per 'sheet per 100 copies, including a coloured wrapper and title-page.

The copies of The Journal of Mental Science are regularly sent by Book-post (prepaid) to the ordinary Members of the Association, and to our Home and Foreign Correspondents, and we shall be glad to be informed of any irregularity in their receipt or overcharge in the Postage.

The following EXCHANGE JOURNALS have been regularly receired since our last publication:

The Annales Médico-Psychologiques; the Zeitschrift für Psychiatrie; the Correspondenz Blatt der deutschen Gesellschaft für Psychyatrie; Archiv für Psy. chiatrie; the Irren Freund; Journal de Médecine Mentale; Archivio Italiuno per le Malattie Nervose e per le Alienazioni Mentali; Medicinische Ahrenlese; Medizinische Jahrbücher (Jeitschrift der $\boldsymbol{K}$. $\boldsymbol{K}$. Gesellschaft der derzte in Wien); the Edinburgh Medical Journal; the American Journal of Insanity; the British and Foreign Medico-Chirurgical Review; the Dublin Quarterly Journal; the Medical Mirror; the Social Science Rovievo; the Ophthalmic Revievo-a Quarterly Journal of Ophthalmic Swrgery and Science; the British Medical Journal; the Medical Circular; and the Jomrnal of the Society of Arts; also the Mcorningside Mirror; the York Star and Excelsior; the Mwrray Royal Institution Literary Gazette.

We are compelled to defer to our next number the publication of the third and fourth papers read at the Annual Meeting of the Medico-Paychological Association, viz.:

"The Pathology of Aphasia." BJ Alexander Robertson, M.D.

"Asylum Architecture" (with plans). By C. Lockhart Robertson, M.D. 